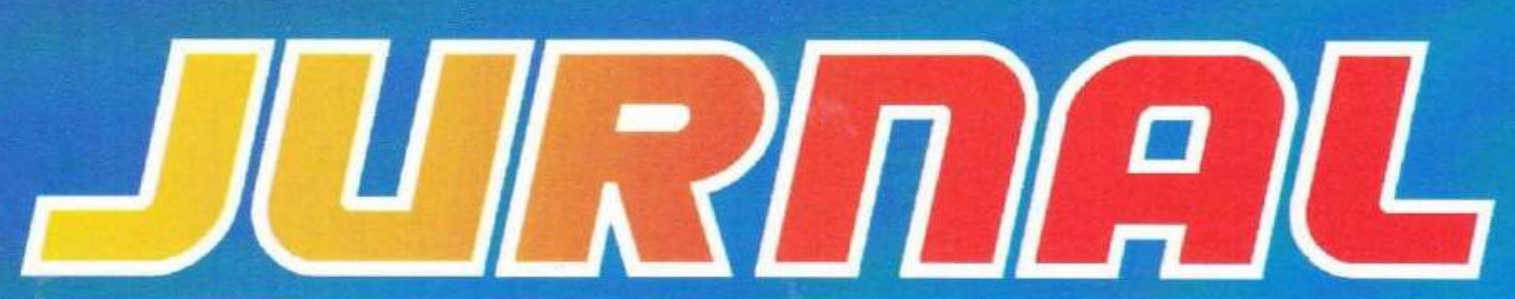

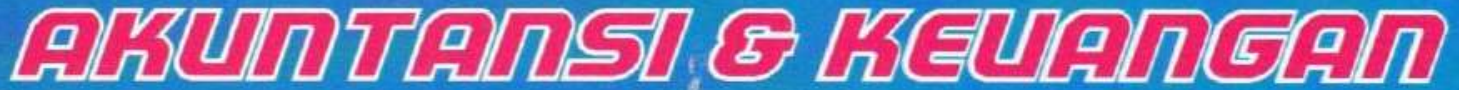

Volume 11, No. 1, Maret 2020

ISSN: $2087-2054$

Analisa Perbandingan Economic Value Added (EVA) Dan Return On Asset (ROA) Dalam Menilai Kinerja Perusahaan (Studi Kasus Pada Perusahaan Rokok Yang Terdaftar Di Bursa Efek Indonesiaperiode 2015-2018).

\section{Dewi Silvia}

Analisis Kinerja Anggaran Pendapatan Dan Belanja Daerah Pada Pemerintah Daerah Kabupaten Oku Periode 2013-2017

Hasiatul Aini, Mardiah Kenamon \& Yeni Anggraini

Analisis Kinerja Keuangan Pemerintah Daerah Oku Selatan Tahun Anggaran 2013-2017. Anis Feblin \& Yulitiawati

Pengaruh Economic Value Added (EVA) Dan Market Value Added (MVA) Terhadap Return Saham.

\section{Luke Suciyati Amna}

Analisis Rasio Keuangan Anggaran Pendapatan Dan Belanja Daerah Untuk Menilai Kinerja Keuangan Pemerintah Daerah Kabupaten Pesawaran Tahun 2010-2014.

\section{Herry Goenawan Soedarsa}

Pengaruh Kualitas Audit Dan Komite Audit Terhadap Kualitas Pelaporan Keuangan Perusahaan Yang Terdaftar Di Jakarta Islamic Index (JII).

\section{Liya Ermawati, Yulistia Devi \& Naurah Nazhifah Arramadani}




\section{JURNAL}

ARUNTANSI \& KEUANGAN

Volume 11, No. 1, Maret 2020

ISSN: $2087-2054$

Dewan Pembina

Dr. Ir. M. Yusuf S. Barusman, M.B.A

Dr. Andala Rama Putra Barusman, S.E., M.A.Ec.

Penanggung Jawab

Aminah, S.E., M.S.Ak

Pimpinan Redaksi

Dr. Haninun, S.E., M.S.Ak

Sekretaris Redaksi

Riswan, S.E., M.S.Ak

Luke Suciyati Amna, S.E., M.S.Ak

\section{Penyuting Ahli (Mitra Bestari)}

Tina Miniawati, S.E., M.B.A. (Universitas Trisakti)

Dr. Khomsiyah, S.E., M.M. (Universitas Trisakti)

Dr. Lindrianasari, S.E., M.Si.Akt., C.A. (Universitas Lampung)

Sujoko Efferin, Mcom (Hons), MA(Econ), Ph.D. (Universitas Surabaya)

\section{Penerbit}

Universitas Bandar Lampung

Fakultas Ekonomi dan Bisnis Program Studi Akuntansi

SENARAI-Jurnal Akuntansi \& Keuangan Terbit 2 kali setahun pada bulan Maret \&

September

Artikel yang dimuat berupa hasil riset Empiris dan telaah teoritis konsepsual yang kritis dalam kajian bidang akuntansi, auditing, perpajakan, dan keuangan.

\section{Alamat Redaksi}

Gedung G- Program Studi Akuntansi Fakultas Ekonomi dan Bisnis

Universitas Bandar Lampung

Kampus A Jalan Z.A Pagar Alam No. 26 Labuan Ratu Bandar Lampung 35142

Telp: (0721) 701979, Fax: (0721) 701467, Email: Prodi.akuntansi@ubl.ac.id 


\section{AKUNTANSI \& KEUANGAN}

Analisa Perbandingan Economic Value Added (EVA) Dan Return On Asset (ROA) Dalam Menilai Kinerja Perusahaan (Studi Kasus Pada Perusahaan Rokok Yang Terdaftar Di Bursa Efek Indonesiaperiode 2015-2018).

\section{Dewi Silvia}

Analisis Kinerja Anggaran Pendapatan Dan Belanja Daerah Pada Pemerintah Daerah Kabupaten Oku Periode 2013-2017

Hasiatul Aini, Mardiah Kenamon \& Yeni Anggraini

Analisis Kinerja Keuangan Pemerintah Daerah Oku Selatan Tahun Anggaran 2013-2017. Anis Feblin \& Yulitiawati

Pengaruh Economic Value Added (EVA) Dan Market Value Added (MVA) Terhadap Return Saham.

\section{Luke Suciyati Amna}

Analisis Rasio Keuangan Anggaran Pendapatan Dan Belanja Daerah Untuk Menilai Kinerja Keuangan Pemerintah Daerah Kabupaten Pesawaran Tahun 2010-2014.

\section{Herry Goenawan Soedarsa}

Pengaruh Kualitas Audit Dan Komite Audit Terhadap Kualitas Pelaporan Keuangan Perusahaan Yang Terdaftar Di Jakarta Islamic Index (JII).

Liya Ermawati, Yulistia Devi \& Naurah Nazhifah Arramadani 


\section{JURNAL}

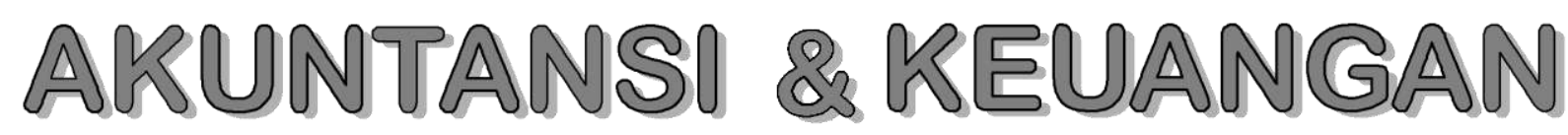

Volume 11, No. 1, Maret 2020

ISSN: $2087-2054$

Daftar Isi

Halaman

Analisa Perbandingan Economic Value Added (EVA) Dan Return On Asset (ROA) Dalam Menilai Kinerja Perusahaan (Studi Kasus Pada

Perusahaan Rokok Yang Terdaftar Di Bursa Efek Indonesiaperiode 2015-2018).

Dewi Silvia

Analisis Kinerja Anggaran Pendapatan Dan Belanja Daerah Pada

Pemerintah Daerah Kabupaten Oku Periode 2013-2017

18-34

Hasiatul Aini, Mardiah Kenamon \& Yeni Anggraini

Analisis Kinerja Keuangan Pemerintah Daerah Oku Selatan Tahun Anggaran 2013-2017.

$35-58$

Anis Feblin \& Yulitiawati

Pengaruh Economic Value Added (EVA) Dan Market Value Added (MVA)

Terhadap Return Saham.

$59-73$

Luke Suciyati Amna

Analisis Rasio Keuangan Anggaran Pendapatan Dan Belanja Daerah Untuk Menilai Kinerja Keuangan Pemerintah Daerah Kabupaten

Pesawaran Tahun 2010-2014.

Herry Goenawan Soedarsa

Pengaruh Kualitas Audit Dan Komite Audit Terhadap Kualitas Pelaporan

Keuangan Perusahaan Yang Terdaftar Di Jakarta Islamic Index (JII).

$92-111$

Liya Ermawati, Yulistia Devi \& Naurah Nazhifah Arramadani 


\section{JURNAL \\ AKUNTANSI \& KEUANGAN}

Volume 11, No. 1, Maret 2020

ISSN: 2087-2054

\section{Informasi Kebijakan dan Selingkung Berkala}

\section{Kebijakan editorial}

JURNAL Akuntansi \& Keuangan adalah sebuah berkala yang dipublikasikan oleh Universitas Bandar Lampung, yang bertujuan untuk menjadi wadah kreatifitas para akademisi, profesional, peneliti, dan mahasiswa di bidang Akuntansi dan Keuangan termasuk juga bidang Auditing, Sistem Informasi Akuntansi, Tata kelola Perusahaan, Perpajakan, Akuntansi Internasional, Akuntansi Managemen, Akuntansi Keperilakuaan, Pasar Modal dan lain sebagainya. Topik yang semakin meluas di bidang kajian riset Akuntansi diakomodir publikasinya di dalam berkala ini.

Paper yang akan dipublikasikan di dalam berkala JURNAL Akuntansi \& Keuangan harus ditulis di dalam bahasa Indonesia yang baik dan sesuai dengan EYD. Semua instrumen yang digunakan untuk memperoleh data penelitian harus dimasukkan di dalam lampiran paper penelitian, paling tidak, penulis bersedia memberikan klarifikasi atas instrumen yang digunakan saat ada permintaan dari peneliti lainnya.

\section{Sekretariat Editor Berkala}

Gedung F - Fakultas Ekonomi Universitas Bandar Lampung

Fakultas Ekonomi Program Studi Akuntansi

Kampus A Jalan Z.A. Pagar Alam No. 26 Labuhan Ratu Bandar Lampung 35142

Telp.: (0721) 701979, Fax.: (0721) 701467, Email:

\section{Petunjuk penulisan}

Artikel yang dikirim ke JURNAL Akuntansi \& Keuangan harus mengikuti petunjuk seperti berikut:

1. Naskah merupakan naskah asli yang belum pernah diterbitkan atau sedang dilakukan penilaian pada berkala lain. Naskah ditulis dalam bahasa Indonesia dengan jarak 1 spasi, sepanjang 20-30 halaman kertas A4 dengan tipe huruf Times New Roman.. Naskah dikirim atau diserahkan ke sekretariat JURNAL Akuntansi \& Keuangan rangkap satu disertai disket berikut dengan biodata penulis dan alamat lengkap (kantor dan rumah) pada lembaran yang terpisah dari halaman pertama artikel.

2. Judul naskah dapat ditulis dengan menggambarkan isi pokok tulisan, dan atau ditulis secara ringkas, jelas, dan menarik.

3. Nama Penulis disertai catatan kaki tentang profesi dan lembaga tempat penulis bekerja dalam naskah yang telah diterima untuk diterbutkan.

4. Abstrak ketik satu spasi, tidak lebih dari 250 kata dalam bahasa Inggris. Abstrak memuat tujuan penelitian, isu, permasalahan, sampel dan metode penelitian, serta hasil dan simpulan (jika memungkinan). 
5. Pendahuluan beriksikan uraian tentang latar belakang masalah, ruang lingkup penelitian, dan telaah pustaka yang terkait dengan permasalahan yang dikaji, serta rumusan hipotesis (jika ada). Uraian pendahuluan maksimum $10 \%$ total halaman.

6. Untuk penelitian kuantitatif,

a. Telaah Literatur dan Pengembangan Hipotesis memuat paling tidak satu buah teori yang menjadi dasar pemikiran penelitian. Hipotesis dikembangkan menggunakan asumsi dasar teori dan hasil penelitian sebelumnya. Telah literatur maksimum $40 \%$ total halaman.

b. Metodologi Penelitian meliputi uraian yang rinci tentang bahan yang digunakan, metoda yang dipilih, teknik, dan cakupan penelitian. Uraian bahan dan metoda maksimum $20 \%$ total halaman.

7. Untuk penelitian kualitatif menyesuaikan dengan metodologi kualitatif.

8. Hasil dan Pembahasan merupakan uraian obyektif dari-hasil penelitian dan pembahasan dilakukan untuk memperkaya makna hasil penelitian. Uraian hasil dan pembahasan minimum $25 \%$ total halaman.

9. Simpulan yang merupakan rumusan dari hasil-hasil penelitian. Harus ada sajian dalam satu kalimat inti yang menjadi simpulan utama. Simpulan maksimum $10 \%$ dari keseluruhan lembar artikel.

10. Referensi (Daftar Pustaka) ditulis berurutan berdasarkan alphabetical, disusun menggunakan suku kata terakhir dari nama penulisnya, atau institusi jika dikeluarkan oleh organisasi.

a. Buku: nama penulis, tahun penerbitan, judul lengkap buku, penyunting (jika ada), nama penerbit, dan kota penerbitan.

b. Artikel dalam buku: nama penulis, tahun penerbitan, judul artikel/tulisan, judul buku, nama penyunting, kota penerbitan, nama penerbit, dan halaman.

c. Terbitan berkala: nama penulis, tahun penerbitan, judul tulisan, judul terbitan (bila disingkat, sebaiknya menggunakan singkatan yang baku), volume, nomor, dan halaman.

d. Artikel dalam internet: nama penulis, judul, dan situsnya.

e. Tabel diberi nomor dan judul dilengkapi dengan sumber data yang ditulis dibawah badan tabel, diikuti tempat dan waktu pengambilan data.

f. Ilustrasi dapat berupa gambar, grafik, diagram, peta, dan foto diberi nomor dan judul.

11. Setiap referensi yang digunakan di dalam naskah artikel menggunakan petunjuk yang dirujuk pada The Indonesian Journal of Accounting Research, sebagai berikut:

A. Kutipan dalam tubuh naskah paper harus disesuaikan dengan contoh berikut:

I. Satu sumber kutipan dengan satu penulis (Brownell, 1981).

II. Satu sumber kutipan dengan dua penulis (Frucot dan Shearon, 1991).

III. Satu sumber kutipan dengan lebih dari satu penulis (Hotstede et al., 1990).

IV. Dua sumber kutipan dengan penulis yang berbeda (Dunk, 1990; Mia, 1988).

V. Dua sumber kutipan dengan satu penulis (Brownell, 1981, 1983).

VI. Dua sumber kutipan dengan satu penulis diterbitkan pada tahun yang sama (Brownell, 1982a, 1982b).

VII. Sumber kutipan dari lembaga harus dinyatakan dengan menggunakan akronim institusi (FASB, 1994)

B. Setiap artikel harus menulis referensi menggunakan panduan berikut:

I. Referensi harus tercantum dalam urutan abjad dari nama belakang penulis atau nama lembaga. 
II. Referensi harus dinyatakan dengan urutan sebagai berikut: penulis (s) nama, tahun publikasi, judul kertas atau buku teks, nama jurnal atau penerbit dan nomor halaman. Contoh:

a) Amerika Akuntansi Association, Komite Konsep dan Standar Laporan Keuangan Eksternal. 1977. Pernyataan tentang Teori Akuntansi dan Teori Penerimaan. Sarasota, FL: AAA.

b) Demski, J. S., dan D. E. M. Sappington. 1989. Struktur hirarkis dan akuntansi pertanggungjawaban, Jurnal Akuntansi Penelitian 27 (Spring): 40-58.

c) Dye, R. B., dan R. Magee. 1989. Biaya Kontijensi untuk perusahaan audit. Kertas kerja, Northwestern University, Evansto, IL.

d) Indriantoro, N. 1993. Pengaruh Penganggaran Partisipatif Terhadap Prestasi Kerja dan Kepuasan Kerja dengan Locus of Control dan Dimensi Budaya sebagai Moderating Variabel. Ph.D. Disertasi. University of Kentucky, Lexington.

e) Naim, A. 1997. Analisis Penggunaan Akuntansi Biaya Produk Dalam Keputusan Harga oligopolistik. Jurnal Ekonomi Dan Bisnis Indonesia 12 (3): 43-50.

f) Porcano, T. M. 1984a. Keadilan distributif dan Kebijakan Pajak. Akuntansi Ulasan 59 (4): 619-636.

g) --------. 1984b. Pengaruh Persepsi Kebijakan Pajak Niat Investasi Perusahaan. The Journal of American Association Perpajakan 6 (Fall): 719.

h) Pyndyk, R. S. dan D. L. Rubinfield. 1987. Model ekonometrik \& Forecasts Ekonomi, 3rd ed. NY: McGraw-Hill Publishing, Inc.

12. Author(s) harus melampirkan CV, alamat email, alamat korespondensi dan pernyataan yang menyatakan pasal tersebut tidak sedang disampaikan kepada atau diterbitkan oleh jurnal lain dalam email tersebut dan /atau pos. 
JURNAL Akuntansi\& Keuangan

Vol. 11, No. 1, Maret 2020

Halaman $59-73$

\title{
PENGARUH ECONOMIC VALUE ADDED (EVA) DAN MARKET VALUE ADDED (MVA) TERHADAP RETURN SAHAM
}

\author{
Luke Suciyati Amna*
}

(Dosen Tetap Fakultas Ekonomi dan Bisnis Universitas Bandar Lampung)

E-mail: luke.suciyati.amna@ubl.ac.id

\begin{abstract}
This study aims to empirically examine the effect of Economic Value Added and Market Value Added on stock returns on property and real estate companies listed on the Indonesian stock exchange, the period used in this study is from 2015-2017. This research uses quantitative methods. The sampling technique in this study used a purposive sampling technique.based on prederemined criteria obtained a sampel of 15 companies for 3 years with 45 observation lists.the data analysis technique used is multiple liniear regression. Based on these results it shows that: Economic Value Added (EVA) has a positive and significant effect on stock returns and Market Value Added (MVA) has a positive and significant effect on stock return.
\end{abstract}

Key words : EVA; MVA; stock Return.

\section{PENDAHULUAN}

Pasar modal merupakan salah satu sarana bagi para pemilik dana atau investor dalam melakukan investasi pada perusahaan yang membutuhkan dana. Menurut Abdul Halim (2005), Investasi pada hakikatnya merupakan penempatan sejumlah dana pada saat ini dengan harapan untuk memperoleh keuntungan di masa mendatang. Investor perlu melakukan analisis saham secara tepat sebelum memutuskan berinvestasi pada saham suatu perusahaan untuk memastikan bahwa investasi tersebut akan memberikan tingkat 
pengembalian (return) yang diharapkan. Analisis yang sering digunakan untuk mengukur kinerja keuangan perusahaan adalah dalam bentuk analisis rasio keuangan. Analisis rasio keuangan dilakukan dengan membandingkan angkaangka yang tercantum di laporan keuangan perusahaan, baik laporan neraca maupun laba rugi. Jika performa yang dilakukan perusahaan bagus, nilai saham perusahaan akan meningkat yang tentu saja akan meningkatkan return saham perusahaan tersebut. Oleh karena itu dalam memprediksi return saham, banyak investor yang melakukan penilaian atau pengukuran terhadap kinerja dan performa perusahaan. Pengukuran terhadap kinerja perusahaan umumnya dilakukan investor dengan menggunkan informasi yang disediakan dalam laporan keungan (Tarmizi dkk, 2018). Salah satunya cara pengukuran yang paling umum adalah menggunakan rasio keuangan.

Secara umum, rasio keuangan diklasifikasikan menjadi lima macam yaitu rasio likuiditas (liquidity ratio), rasio aktivitas (activity ratio), rasio hutang (leverage ratio), rasio profitabilitas (profitability ratio), dan rasio nilai pasar (Warsono, 2003). Analisis kinerja keuangan perusahaan menggunakan rasio keuangan memiliki kelemahan, seperti yang diungkapkan oleh Ekaningsih (2011) "pengukuran yang hanya menganalisis laporan keuangan memiliki kelemahan utama yaitu mengabaikan adanya biaya modal, sehingga sulit untuk mengetahui apakah suatu perusahaan telah berhasil menciptakan nilai atau tidak". Menurut Stern dan Stewart, pendiri perusahaan konsultan Stern Stewart \& Company di Amerika Serikat (1989), memperkenalkan metode baru yaitu Economic Value Added (EVA) dan Market Value Added (MVA) sebagai alat ukur kinerja keuangan untuk mengatasi kelemahan metode sebelumnya (rasio keuangan). Fenomena yang membuat EVA berbeda dengan perhitungan konvensional lain adalah digunakannya biaya modal dalam perhitungannya, yang tidak dilakukan dalam perhitungan konvensional (Singgih, 2008). 
Muiszudin dan Budiarti (2016), meneliti tentang pengaruh Economic Value Added (EVA) Dan Market Value Added (MVA) terhadap return saham pada perusahaan yang di perdagangkan di BEI. Hasil penelitian menunjukkan bahwa variabel EVA dan MVA berpengaruh terhadap return saham. Penelitian Babatunde dan Evuebie (2017), menunjukkan bahwa Economic Value Added (EVA) berpengaruh terhadap return saham. Sejalan dengan hasil penelitian yang dilakukan Awan, dkk, (2014) menunjukkan bahwa Economic Value Added (EVA) berpengaruh signifikan terhadap return saham. Hasil penelitian tersebut mendukung pernyataan bahwa semakin baik kinerja keuangan yang diperoleh, maka semakin tinggi pula nilai perusahaan. Akan tetapi beberapa penelitian menunjukkan ketidakkonsistenan mengenai pengaruh kinerja keuangan tersebut terhadap return saham.

Nugroho dan Sarsiti (2015) yang meneliti tentang pengaruh Economic Value Added (EVA) Dan Market Value Added (MVA) terhadap return saham pada perusahaan manufaktur di BEI mengungkapkan bahwa EVA tidak mempunyai pengaruh positif terhadap return saham dan variabel MVA tidak mempunyai pengaruh positif yang signifikan terhadap return saham. Hasil penelitian tersebut sesuai dengan penelitian yang dilakukan oleh Rahayu dan Aisjah (2013) meneliti tentang pengaruh Economic Value Added dan Market Value Added terhadap return saham perusahaan yang terdaftar dalam Indeks LQ45 tahun 2009-2011 menyatakan bahwa secara parsial EVA maupun MVA tidak berpengaruh terhadap return saham yang diterima oleh pemegang saham dan secara simultan menunjukkan bahwa variabel EVA dan MVA secara bersama-sama tidak memiliki pengaruh terhadap return saham.

Berdasarkan pengujian-pengujian yang telah dilakukan oleh berbagai peneliti terdahulu masih terdapat perbedaan hasil penelitian mengenai kinerja keuangan perusahaan yang berpengaruh terhadap return saham, karena tidak 
semua kinerja keuangan mempunyai pengaruh yang positif dan signifikan terhadap return saham sebab lain juga bisa dijadikan tolak ukur dalam mengambil keputusan investasi misalnya terjadinya krisis atau faktor ekonomi lainnya. Untuk menghetahui pengaruh Economic Value Added (EVA) dan Market Value Edded (MVA) terhadap return saham (Studi Empiris Pada Perusahaan Properti dan Real Estate yang Terdaftar di Bursa Efek Indonesia (BEI) Periode Tahun 2015-2017)".

\section{KAJIAN PUSTAKA DAN HIPOTESIS}

Penelitian ini menggunakan teori sinyal menjelaskan alasan perusahaan menyajikan informasi untuk pasar modal (wolk, dkk, 2001). Teori sinyal menunjukan adanya asimetri informasi antara menejemen perusahaan dan menunjukan adanya asimetri informasi antara menejemen perusahaan dan pihak-pihak yang berkepentingan dengan informasi tersebut. Teori sinyal mengemukakan tentang bagaimana seharusnya perusahaan memberikan sinyalsinyal pada pihak-pihak yang berkepentingan. informasi yang dipublikasi sebagai suatu pengumuman akan memberikan sinyal bagi investor dalam mengambil keputuan investasi. Jika pengumuman tersebut mengandung nilai positif, maka diharapkan pasar akan bereaksi pada saat pengumuman tersebut diterima oleh pasar (Hartono, 2000).

Variabel dependen dalam penelitian ini adalah Return Saham merupakan salah satu faktor yang memotivasi investor berinvestasi dan merupakan imbalan atas keberanian investor menanggung risiko atas investasi yang dilakukannya (Eduardus, 2001). Jogiyanto (2010) membedakan return saham menjadi 2, yaitu: Return Realisasi (relized return) merupakan return yang sudah terjadi yang dihitung berdasarkan data historis. Return Ekspektasi (expected return) merupakan return yang diharapkan dimasa mendatang dan masih bersifat tidak pasti. 
Variabel independen yaitu Economic Value Added dan Market Value Added. Brigham (2010) menyatakan bahwa EVA adalah cara untuk mengukur profitabilitas operasi yang sesungguhnya. Biaya modal hutang (beban bunga) dikurangkan ketika menghitung laba bersih tetapi biaya ini tidak dikurangkan pada saat menghitung biaya modal ekuitas. Menurut Brigham dan Houston (2010), mendefinisikan Market Value Added (MVA) adalah suatu metode yang mengukur kemampuan perusahaan untuk meningkatkan dana para pemegang saham. Tujuan utama perusahaan tidak hanya memaksimalkan kekayaan pemegang saham, tetapi juga membantu untuk memastikan bahwa sumber daya yang terbatas telah dialokasikan secara efisien, yang akan memberikan keuntungan pada ekonomi.

Penelitian yang dilakukan Anggreni, dkk (2017) menunjukkan bahwa Economic Value Added (EVA) berpengaruh positif dan signifikan terhadap return saham. Penelitian ini didukung Hidayat (2011), bahwa Economic Value Added (EVA), Market Value Added dan Earning Per Share memiliki pengaruh positif dan signifikan terhadap return saham. Hasil penelitian ini menujukkan bahwa perusahaan telah berhasil menciptakan nilai bagi pemilik modal dan dapat mendorong permintaan terhadap saham perusahaan akan semakin banyak, sehingga berdampak pada ketertarikan investor untuk menginvestasikan saham. Tingginya EVA menandakan bahwa perusahaan memiliki profit yang tinggi karena perusahaan mampu untuk memenuhi kewajibannya. Ketika laba perusahaan semakin tinggi maka dividen yang didapat oleh para pemegang saham juga semakin tinggi.Perusahaan yang memiliki EVA yang tinggi cenderung dapat lebih menarik investor untuk berinvestasi diperusahaan tersebut, karena semakin tinggi EVA maka semakin tinggi pula nilai perusahaan. 
H1 : Economic Value Added (EVA) berpengaruh positif dan signifikan terhadap Return Saham

Penelitian yang dilakukan oleh Anggreni, ddk (2017) bahwa Market Value Added (MVA) memiliki pengaruh positif dan signifikan terhadap return saham. Hasil penelitian tersebut sama dengan penelitan yang dilakukan oleh Kusuma (2018), bahwa Market Value Added (MVA) memiliki pengaruh positif signifikan terhadap return saham. Konsep Market Value Added (MVA) mengacu pada nilai total yang pasar berikan pada semua saham perusahaan dikurangi biaya modal yang diinvestasikan. Market Value Added (MVA) yang positif menunjukkan bahwa nilai pasar perusahaan lebih tinggi dibandingkan dengan nilai buku perusahaan. Hal ini berarti bahwa apabila nilai Market Value Added (MVA) perusahaan mengalami kenaikan maka return yang akan diterima oleh para investor juga akan mengalami kenaikan dan sebaliknya. Sehingga, kekayaan atau kesejahteraan pemilik perusahaan akan bertambah bila MVA bertambah melalui meningkatnya capital gain dari meningkatnya harga saham.Semakin tinggi capital gain dan dividen, maka return saham yang diperoleh pemegang saham juga akan bertambah.

H2 : Market Value Added (MVA) berpengaruh positif dan signifikan terhadap Return Saham.

\section{METODOLOGI PENELITIAN}

Jenis penelitian yang digunakan adalah penelitian kausalitas, yaitu penelitian yang bertujuan untuk membuktikan hubungan sebab-akibat atau hubungan yang mempengaruhi dan dipengaruhi dari variabel-variabel yang diteliti. Sumber data yang digunakan adalah sumber data sekunder. Populasi pada penelitian ini adalah keseluruhan perusahaan properti dan Real Estet yang terdaftar di Bursa Efek Indonesia (BEI) tahun 2015-2017, yang diakses melalui 
website resmi Bursa Efek Indonesia yaitu www.idx.co.id. Teknik yang digunakan dalam pengambilan sampel menggunakan metode purposive sampling. Penelitian ini digunakan untuk menganalisis pengaruh Economic Value Added (EVA) dan Market Value Added (MVA) terhadap Return saham. Dat yang diperoleh dianalisis menggunakan analsis regresi linear berganda. Untuk membantu proses pemgolahan data dilakukan dengan menggunakan program Statistical Package for social science (SPSS) 18.0 for windows.

\section{Model Penelitian dan Pengujian Statistik}

model persamaan regresi secara sistematik dapat dirumuskan sebagai berikut:

$$
\begin{aligned}
& \mathrm{Ri}=\alpha+\beta_{1} \mathrm{EVA}+\beta_{2} \mathrm{MVA}+\varepsilon \\
& \text { Keterangan : } \\
& \text { Ri = Variabel Return saham } \\
& \alpha=\text { Kostanta } \\
& \beta_{1} \quad=\text { Koefisien regresi variabel independen EVA } \\
& \text { EVA = variabel EVA } \\
& \beta_{2} \quad=\text { Koefisien regresi variabel independen MVA } \\
& \text { MVA = Variabel MVA } \\
& \varepsilon \quad=\text { error term }
\end{aligned}
$$

\section{HASIL DAN PEMBAHASAN}

Data yang digunakan dalam penelitian ini adalah laporan keuangan perusahaan Properti dan Real Estate yang terdaftar Bursa Efek Indonesia (BEI) selama periode tahun 2015-2017. Populasi dalam penelitian ini adalah Perusahaan Properti dan Real Estate yang terdaftar di Bursa Efek Indonesia sebanyak 61 perusahaan. Pengambilan sampel dalam penelitian ini dilakukan 
dengan menggunakan teknik purposive sampling. Berdasarkan kriteria yang ditentu.kan terdapat 15 perusahaan yang menjadi sampel selama tiga tahun dengan 45 data observasi

\section{Uji Asumsi Klasik}

Uji Normalitas Kolmogorov-Smirnov Test

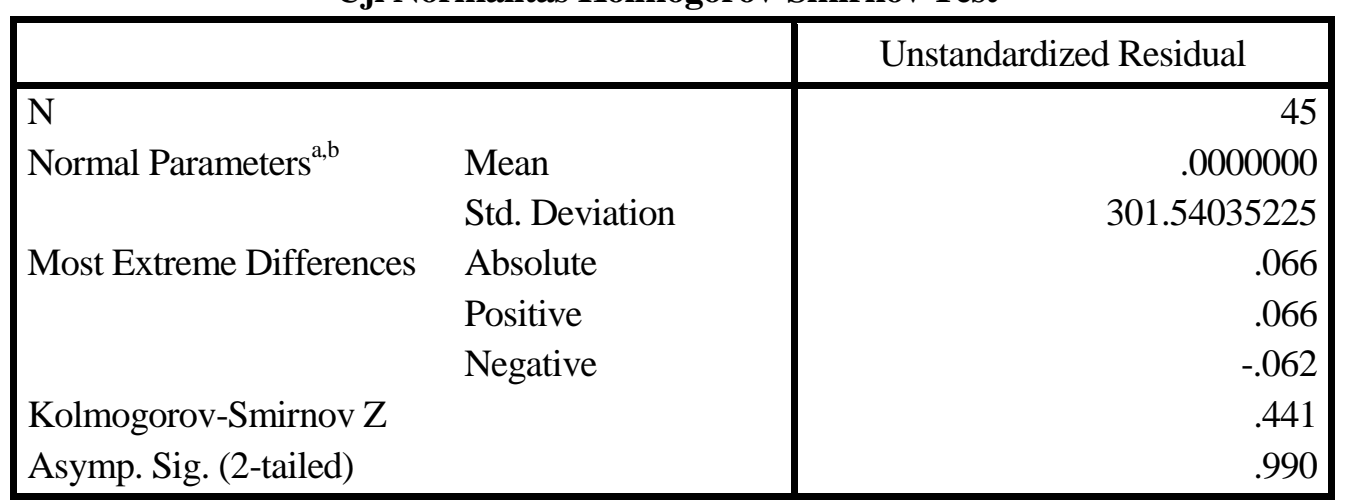

a. Test distribution is Normal.

b. Calculated from data.

Sumber : Hasil olah data sekuunder melalui SPSS, tahun 2020

Berdasarkan hasil uji normalitas menggunakan Uji Kolmogorov Smirnov, hasil pengolahan data menunjukkan bahwa data berdistribusi normal.Hal ini dibuktikan dengan hasil Uji K-S yang menunjukkan nilai Asymph. Sig (2tailed) di atas tingkat signifikansi 0,05, yaitu sebesar 0,990. Hal ini menunjukkan bahwa data berdistribusi normal. 
Hasil Uji Multikolinearitas

\begin{tabular}{|ll|r|r|}
\hline \multirow{2}{*}{ Model } & \multicolumn{2}{|c|}{ Collinearity Statistics } \\
\cline { 2 - 3 } & (Constant) & Tolerance & \multicolumn{1}{|c|}{ VIF } \\
\hline 1 & & .915 & 1.092 \\
& EVA & .915 & 1.092 \\
& MVA & & \\
\hline
\end{tabular}

a. Dependent Variable: Return Saham

Sumber : Hasil olah data sekunder melalui SPSS, tahun 2020

Berdasarkan hasil uji multikolinearitas diperoleh nilai tolerance untuk variabel Economic Value Added (EVA) sebesar 0,915, Market Value Added (MVA) sebesar 0,915 menunjukan nilai tolerance lebih besar dari 0,10. Begitu pula dengan nilai VIF Economic Value Added (EVA) sebesar 1,092 dan Market Value Added (MVA) sebesar 1,092. Hasil statistik menunjukan nilai VIF dari kedua variabel tersebut menunjukkan lebih kecil dari 10. Maka dapat disimpulkan bahwa kedua variabel tersebut bebas dari masalah multikolinearitas yang berarti tidak terjadi korelasi diantara variabel independent. 


\section{Hasil Uji Glejser}

\begin{tabular}{|l|c|}
\hline \multicolumn{1}{|c|}{ Model } & \multicolumn{2}{|c|}{ Sig. } \\
\hline (Constant) & .001 \\
EVA & .351 \\
MVA & .072 \\
\hline
\end{tabular}

a. Dependent Variable: RES2

Sumber : Hasil olah data sekunder melalui SPSS, tahun 2020

Berdasarkan hasil uji heterokedastisitas pada tabel diatas dengan menggunakan uji Glejser, dapat dilihat bahwa dari ke dua variabel yang digunakan didalam penelitian ini tidak terdapat masalah heterokedastisitas, karena masing-masing variabel memberikan nilai signifikan diatas 0,05 .

\section{Hasil Uji Autokorelasi}

\begin{tabular}{|l|r|r|r|r|r|}
\hline Model & R & R Square & $\begin{array}{l}\text { Adjusted } \\
\text { R Square }\end{array}$ & $\begin{array}{r}\text { Std. Error of } \\
\text { the Estimate }\end{array}$ & $\begin{array}{c}\text { Durbin- } \\
\text { Watson }\end{array}$ \\
\hline 1 & $.772^{\mathrm{a}}$ & .596 & .543 & 274.31586 & 1.795 \\
\hline
\end{tabular}

a. Predictors: (Constant), MVA, EVA

b. Dependent Variable: Return Saham

Sumber : Hasil olah data sekunder melalui SPSS, tahun 2020

Bedasarkan tabel diatas nilai Durbin-Watson sebesar 1,795 dengan jumlah data $(\mathrm{n})=45$, maka diperoleh nilai $\mathrm{Du}=1,6148$ dan 4-Du $=2,3852$ kerena nilai DW berada pada daerah autokorelasi positif maka tidak terdapat korelasi antara kesalahan pada periode sebelum nya. 


\section{Uji Regresi Linier Berganda}

\section{Coefficients $^{\mathrm{a}}$}

\begin{tabular}{|c|c|c|c|c|c|c|}
\hline \multirow{2}{*}{\multicolumn{2}{|c|}{ Model }} & \multicolumn{2}{|c|}{$\begin{array}{l}\text { Unstandardized } \\
\text { Coefficients }\end{array}$} & \multirow{2}{*}{$\begin{array}{c}\begin{array}{c}\text { Standardized } \\
\text { Coefficients }\end{array} \\
\text { Beta }\end{array}$} & \multirow[b]{2}{*}{$\mathrm{T}$} & \multirow[b]{2}{*}{ Sig. } \\
\hline & & B & $\begin{array}{l}\text { Std. } \\
\text { Error }\end{array}$ & & & \\
\hline \multirow[t]{3}{*}{1} & (Constant) & 10.72 & 9.79 & & 10.95 & .000 \\
\hline & EVA & .047 & .020 & .327 & 2.357 & .023 \\
\hline & MVA & .190 & .053 & .497 & 3.577 & .001 \\
\hline
\end{tabular}

Sumber : Hasil olah data sekunder melalui SPSS, tahun 2019

Dari hasil tabel diatas, maka persamaan regresi yang dihasilkan adalah sebagai berikut :

$R i=10,72+0,047 E V A+0,190 M V A+\varepsilon$

Persamaan tersebut menunjukan arah masing-masing variabel bebas EVA dan MVA terhadap variabel terikat memiliki pengaruh positif.

\section{PENGUJIAN HIPOTESIS}

\section{Pengaruh Economic Value Added terhadap Return Saham}

Hasil analisis statistik untuk variabel Economic Value Added (EVA) diketahui bahwa nilai t hitung bernilai positif sebesar 2,327. Hasil statistik uji t untuk EVA diperoleh nilai signifikan sebesar 0,023 dimana lebih kecil dari 0,05, sehingga dapat disimpulkam bahwa EVA berpengaruh positif dan signifikan terhadap return saham, sehingga hipotesis diterima. Teori sinyal (wolk, dkk 2001), menyatakan bahwa EVA yang tinggi akan memberikan sinyal-sinyal kepada investor untuk mengambil keputusan investasi. Hasil penelitian ini menujukkan bahwa perusahaan telah berhasil menciptakan nilai 
bagi pemilik modal dan dapat mendorong permintaan terhadap saham perusahaan akan semakin banyak, sehingga berdampak pada ketertarikan investor untuk menginvestasikan saham. Tingginya EVA menandakan bahwa perusahaan memiliki profit yang tinggi karena perusahaan mampu untuk memenuhi kewajibannya. Ketika laba perusahaan semakin tinggi maka dividen yang didapat oleh para pemegang saham juga semakin tinggi. Perusahaan yang memiliki EVA yang tinggi cenderung dapat lebih menarik investor untuk berinvestasi diperusahaan tersebut, karena semakin tinggi EVA maka semakin tinggi pula nilai perusahaan. Dari hasil penelitian ini, dapat menyatakan bahwa Economic Value Added berpengaruh positif terhadap Return saham.

\section{Pengaruh Market Value Added terhadap Return Saham}

Hasil analisis statistik untuk variabel Market Value Added (MVA) diketahui bahwa nilai t hitung bernilai positif sebesar 3,577. Hasil statistic uji t untuk MVA diperoleh nilah signifikan sebesar 0,001, dimana lebih kecil dari toleran kesalahan $\alpha=0,05$, sehingga dapat disimpulkan bahwa MVA berpengaruh positif dan signifikan terhadap return saham, sehingga hipotesis kedua diterima. Market Value Added (MVA) yang positif menunjukkan bahwa nilai pasar perusahaan lebih tinggi dibandingkan dengan nilai buku perusahaan. Hal ini berarti bahwa apabila nilai Market Value Added (MVA) perusahaan mengalami kenaikan maka return yang akan diterima oleh para investor juga akan mengalami kenaikan dan sebaliknya. Sehingga, kekayaan atau kesejahteraan pemilik perusahaan akan bertambah bila MVA bertambah melalui meningkatnya capital gain dari meningkatnya harga saham. Semakin tinggi capital gain dan dividen, maka return saham yang diperoleh pemegang saham juga akan bertambah. Teori sinyal (wolk, dkk 2001), menyatakan bahwa MVA yang tinggi akan memberikan sinyal-sinyal kepada investor dalam mengambil keputusan investasi berupa informasi yang dipublikasi sebagai suatu pengumuman. Jika pengumuman tersebut mengandung nilai positif, 
maka pasar akan bereaksi pada saat pengumuman diterima oleh pasar (Hartono, 2000).

\section{KESIMPULAN DAN SARAN}

\section{Kesimpulan}

Berdasarkan hasil penelitian seperti yang telah dijelaskan, maka dapay disimpulkan bahwa Economic Value Added berpengaruh positif dan signifikan terhadap return saham dan Market Value Added berpengaruh positif dan signifikan terhadap return saham.

\section{Saran}

a. Bagi perusahaan diharapkan dapat meningkatkan kinerja perusahaan khususnya pada kinerja keuangan pada setiap tahunnya. Kinerja perusahaan yang baik, akan berpengaruh pada meningkatnya harga saham dan meningkatkan harapan return saham yang dapat diterima investor.

b. Bagi investor dalam menganalisis kinerja keuangan suatu perusahaan, selain menggunakan rasio keuangan sebaiknya memperhatikan variabel Economic Value Added (EVA) dan Market Value Added (MVA) sebagai dasar acuan ataupun bahan pertimbangan dalam pengambilan keputusan investasi yang efektif dan optimal.

c. Bagi peneliti selanjutnya disarankan untuk menambahkan faktor eksternal maupun faktor internal lainnya untuk mencari variabel-variabel yang berpengaruh terhadap return saham yang diterima investor, menambah periode penelitian yang panjang serta memperbanyak jumlah sampel sehingga mendapatkan hasil pengolahan data yang lebih baik dan mendapatkan kesimpulan yang lebih luas. 


\section{DAFTAR PUSTAKA}

Abdul, H. (2005). Analisi Investasi. Edisi Kedua. Jakarta. Salemba Empat.

Anggreni, P.D., Sujana dan Purnamawati G.A. (2017). Pengaruh Operating Laverage, Economic Value Added dan Market Value Added terhadap Return Saham perusahaan Property dan Real Estate. Jurnal Akuntansi Program S1, Vol. 61 No. 3.

Ansori. (2015). Pengaruh Economic Value Added dan Market Value Added terhadap Return Saham pada Perusahaan Manufaktur yang terdaftar di Bursa Efek Indonesia. Jurnal Ekonomi. Universitas Negeri Yogyakarta.

Awan, A.G. (2014). "The Effect Of Economic Value Added On Stock Return: Evidence From Selected Companies Of Karachi Stock Exchange". Research Journal of Finance and Accounting.Vol.5, No. 23.

Babatunde, A.A., dan Evuebie, O.C. (2017). The Impact of Economic Value Added $\left(\mathrm{EVA}^{\mathrm{TM}}\right)$ on Stock Return in Nigeria.Journal Business and Management. Vol. 4(2):89-93.

Brigham dan Houston.(2010). Dasar-dasar Manajemen Keuangan. Buku Satu. Edisi 11. Jakarta: Salemba Empat.

Eduardus, T. (2001).Analisis Keuangan dan Manajemen Portofolio.Yogyakarta : BPEE.

Ekaningsih, Lely., A.F. (2011). Analisis Perbandingan Penilaian Kinerja Perusahaan Di Bursa Efek Indonesi. Jurnal Akuntansi Universitas Jember.

Hidayat, A. (2011). Pengaruh Economic Value Added, Market Value Added dan Earning Per Share terhadap Return Saham. Jurnal Ekonomi Vol 1, Nomor 1.

Jogiyanto, H.M. (2015). Teori Portofolio dan Analisis Investasi. Edisi Sepuluh. Penerbit BPFE Yogyakarta.

Kusuma, R.A. (2018). Pengaruh Economic Value Added (EVA) dan Market Value Added (MVA) Terhadap Return Saham Perusahaan yang terdaftar dalam Indeks LQ45 di BEI. Jurnal Administrasi bisnis, Vol. 61, No. 3. 
Muiszudin dan Budiarti.(2016). Pengaruh Economic Value Added (EVA) Dan Market Value Added (MVA) Terhadap Return Saham Pada Perusahaan Yang Diperdagangkan Di Bursa Efek Indonesia. Jurnal Manajemen MOTIVASI.

Rahayu, U.T., dan Aisjah, S. (2013). Pengaruh Economic Value Added dan Market Value Added Terhadap Return Saham.Jurnal Ilmiah Mahasiswa Fakultas Ekonomi dan Bisnis, Universitas Brawijaya. Malang. Vol 2, No 1: Semester Ganjil 2013/2014.

Rahmadi Y.D.(2013). Pengaruh Earning Per Share, Arus Kas Operasi, Economic Value Added, dan Market Value Added Terhadap Return Saham Perusahaan Manufaktur yang tedaftar di BEI. Jurnal Akuntansi Program S1 : Universitas Negeri Padang.

Tarmizi, R., Indrayenti., Herry, G.S. (2018). Pengaruh Likuiditas dan Profitabilitas terhadap Return Saham. Jurnal Akuntansi dan Keuangan. Vol. 9, No.1, Hal. 21-33.

Warsono.(2003). Manajemen Keuangan Perusahaan. Edisi Ketiga. Cetakan Pertama. Jilid Satu. Bayu Media. Malang.

Widasari, Ela dan Hanifah. (2018). Pengaruh Return On Equity (ROE), Earning Per Share (EPS), Economic Value Added (EVA), dan Market Value Added (MVA) terhadap Return Saham. Jurnal akuntansi.Vol.6, No. 1.

Wolk, dkk. (2001)."Signaling Agency Theory, Accounting Policy Choice".accounting and Business Research. Vol. 18, No. 69, Hal.47-56.

Sumber Lain:

$\underline{\text { www.idx.co.id }}$

www.Finance yahoo.com 